\title{
Effects on Productivity, Physiology and Biochemistry From Introducing Zeolite Sourced From Lyulinskoye Deposit into Animal Diet
}

\author{
Satkeeva Amina Bestaevna \\ Northern Trans-Ural State Agricultural University \\ Tyumen, Russia \\ E-mail: satkeeva.a@mail.ru
}

\begin{abstract}
The paper presents the research results for using zeolite from Lyulinskoye deposit (Khanty-Mansi Autonomous Region) in nutrition of young pig stock. Mineral and radionuclide composition of zeolith have been studied. It has been found that the zeolith is a mixture of minerals: clinoptilolite (about $50 \%$ ), montmorillonite and bentonite clays (up to $25 \%$ ), silica sand (up to $15 \%$ ); its chemical composition is mainly represented by aluminum silicates: silicon dioxide and aluminum dioxide, as well as macro- and micronutrients. Concentrations of artificial and natural radionuclides in the zeolite have been determined. Content of natural radioactive elements in the zeolite corresponds to the values of medium active sedimentary rocks that are not dangerous for animals. It has been established that use of feed mixes with a zeolite additive normalizes metabolism and provides productivity growth. It has been established that introduction of zeolite ( 2 and $3 \%$ of dry weight) into diet had a positive impact on digestibility of feeds, metabolism and body defenses. It has allowed increasing gross live weight gain of pigs in experimental groups by 16.8 and $25.1 \%$, slaughter yield by 1.5 and $2.8 \%$ and reducing feed consumption per a unit of live weight gain by 3.8 and $5.2 \%$ comparing to the control group.
\end{abstract}

Keywords-Female pigs, digestibility, metabolic energy, gross gain, slaughter yield, blood, erythrocytes, zeolite

\section{INTRODUCTION}

One of prioritized directions of agricultural policy in Russia is to increase the share of domestic meat producers in the market, increase their competitive ability and investment attractiveness $[1,9,13]$. One of the main condition for reaching the stated objectives is a continuous improvement of the feeding system by means of replenishing the feeds with deficient elements necessary for critical processes in animal organism. However, content of minerals and their quantitative ratio in feeds not always meet the requirements imposed by animal organisms [2, 9], leading to organism malfunctions, reduced productivity, excess consumption of feeds and undersupply of animal products.

Research objective was to study chemical and radionuclide composition of zeolite from Lyulinskoye deposit and its influence on physiological and biochemical indicators of female pigs.

\section{MATERIAL AND METHODS OF RESEARCH}

The experimental part of the work was performed at an instructional and experimental farm of the North Trans-Ural State Agricultural University. To accomplish the tasks, four groups of Large White female pigs were selected with considerations for age, live weight and physiological condition; each group included 10 animals. Feeding and housing conditions were the same for all groups, with the only exception that the female pigs in the 1st experimental group in addition to the main diet were getting $2 \%$ of zeolite (measured as percentage of dry weight) from Lyulinskoye deposit (KhantyMansi Autonomous Region). Those in the 2nd experimental group were getting $3 \%$ of zeolite, those in the 3 rd experimental group were getting $4 \%$ of zeolite.

The chemical composition of the zeolite was determined from a microscale X-ray fluorescence analysis performed with a DRON-2.0, Fe-K $\Delta$ instrument. Content of natural and artificial radionuclides in dry mineral was determined at a Gamma-Plus Multi-purpose spectrometric complex.

Effect of the studied additive was assessed by its influence on feed digestibility, energy metabolism, nitrogen and mineral content in pig organisms. Physiological condition of the female pigs was determined from hematological and biochemical indicators. Productive effect was measured by changes in live weight and meat production of the experimental animals.

\section{THE RESULTS OF THE STUDY AND THEIR DISCUSSION}

One of the serious global environmental problems is pollution of environment that leads to increased concentration of various toxins in animal feeds, resulting in metabolic disorders, reduced reproductivity and productivity of animals $[3,4,15]$. To reduce the environmental load on organisms and increase animal productivity, natural silica complexes such as zeolite, bentonite and others, sourced from various deposits are widely used in many regions of our country. At the same time, aluminum silicates are good sorbents of various toxins always present in feeds or those formed as a result of metabolism; thus, they facilitate their removal from organism. Zeolites of different regions and natural deposits differ by their geological genesis, impurity content (such impurities may be dangerous 
for organisms), elemental composition, and structure, physical and chemical properties [5, 9].

The studies have shown that the mineral composition of zeolite sourced from Lyulinskoye deposit includes about 50\% of clinoptilolite, up to $25 \%$ of montmorillonite and bentonite clays and up to $15 \%$ of silica sand. The chemical composition of the zeolite is largely represented with aluminum silicates: silicon dioxide $(56.7 \%)$, aluminum oxide $(16.2 \%)$, besides, they contain calcium $(5.9 \%)$, iron $(4.7 \%)$, magnesium $(2.4 \%)$, potassium $(1.4 \%)$, sodium $(0.8 \%)$, manganese $(0.29 \%)$, phosphorus $(0.13 \%)$, copper $(0.03 \%)$, zinc $(0.01 \%)$, sulfur $(0.02 \%)$. Content of toxic elements, such as fluoride, arsenic, mercury, lead, cadmium in the studied zeolite is below maximum allowable concentration levels (less than $0.001 \%$ ).

In recent years, a special attention has been being paid to biological action of ionizing radiation, radioecology of soils and plants, behavior of radionuclides in various natural zones of Russia. Small doses of ionizing radiation facilitate reparation of chemical damage to DNA by activating formation of specific ferments, thus reducing the number of genetic mutations [12].

Radiometric analysis has shown concentration of artificial radioactive isotopes of strontium $\left({ }^{90} \mathrm{Sr}\right)$ and cesium $\left({ }^{137} \mathrm{Cs}\right)$ below the maximum allowable levels. Concentration of natural radioactive isotopes corresponded to a medium active sedimentary rock and on average, for radium $\left({ }^{226} \mathrm{Ra}\right)$ it was equal to $25.5 \mathrm{~Bq}$, for thorium $\left({ }^{232} \mathrm{Th}\right)$ it was equal to $11.8 \mathrm{~Bq}$, and for potassium $\left({ }^{40} \mathrm{~K}\right)$ it was equal to $525.0 \mathrm{~Bq}$. Content of artificial radioactive isotopes of strontium $\left({ }^{90} \mathrm{Sr}\right)$ and cesium $\left({ }^{137} \mathrm{Cs}\right)$ did not exceed allowable levels. Total activity of alphaand beta-radiating isotopes corresponded to low doses of radiation of 452.0 and $676.0 \mathrm{~Bq}$, respectively. Effective activity did not exceed the level set as allowable for agricultural ores at 85.6 Bq/ $\mathrm{kg}$, thus, allowing using zeolite from Lyulinskoye deposit as a mineral additive.

Nutritional value of a diet is determined by digestibility of its components. Introduction of $3 \%$ of zeolite by dry weight into the diet of female pigs has not only improved nutritional quality of the feed, but benefited digestion processes, resulting in digestibility increased by $2.01 \%$ for dry weight $(\mathrm{P}<0.01)$, by $1.76 \%(\mathrm{P}<0.01)$ for organics, by $3.50 \%(\mathrm{P}<0.05)$ got raw protein, by $1.34 \%(\mathrm{P}<0.001)$ for nitrogen-free extractive substances. The pigs that got 2 and $4 \%$ of zeolite as a percentage of feed dry weight increased digestibility by 0.89 and $0.64 \%$ as calculated for dry weight, by 2.84 and $1.94 \%$ for organics, by 2.61 and $1.53 \%$ for raw fat, by 0.82 and $0.59 \%$ for raw fiber, by $0.83(\mathrm{P}<0.05)$ and $0.85 \%(\mathrm{P}<0.05)$ for nitrogen-free extractive substances as compared to control. Probably, introduction of the zeolite being studied into pigs' diet somewhat stabilized their intestines, leading to improved digestibility of nutrients.

Energy metabolism is an indicator of general condition and physiological activity of an animal organism. Thus, female pigs getting $3 \%$ of zeolite as percentage of dry weight in their diet reliably exceeded the values shown by the control animals in gross energy by $9.5 \%(\mathrm{P}<0.05)$, in digested energy by $16.7 \%$ $(\mathrm{P}<0.05)$, in energy metabolism by $12.0 \%(\mathrm{P}<0.05)$, in net growth energy by $20.3 \%(\mathrm{P}<0.05)$. When female pigs were fed 2 and $4 \%$ zeolite as percentage of dry weight, the digested energy increased by $13.7(\mathrm{P}<0.05)$ and $9.5 \%$, productive energy increased by 7,1 and $1.5 \%$, metabolic energy by 9.0 and $5.2 \%$, net growth energy by $14.0(\mathrm{P}<0.05)$ and $14.9 \%(\mathrm{P}<0.05)$ in comparison to control animals.

The main problem limiting animal productivity is deficiency of feed protein. Protein deficiency in organism leads to a sharp drop in glycogen, decreased ferment activity, malfunction of organism activity, overconsumption of feeds and increased costs of production. Maximum nitrogen retention was registered in the organisms of female pigs pertaining to the 2nd experimental group, significantly larger, by $17.6 \%$ $(\mathrm{P}<0.05)$, than the control. In the 1 st and the $3 \mathrm{rd}$ experimental groups, the female pigs retained 9.0 and $5.0 \%$ more nitrogen than the control.

Enrichment of pig diet with zeolite sourced from Lyulinskoye deposit increased digestibility of calcium and phosphorus, having a positive impact on mineral exchange. However, the female pigs of the 2nd experimental group had reliably retained $17.5(\mathrm{P}<0.01)$ and $17.8 \%(\mathrm{P}<0.05)$ more calcium and phosphorus respectively, as compared to control. Experimental animals in the 1st and 3rd experimental groups retained 13.1 and $11.0 \%$ more calcium, and 9.8 and $10.8 \%$ more phosphorus compared to the control group.

Blood indicators best represent the level and rate of exchange processes under influence of various factors and development of various adaptive or pathological processes. Morphological indicators of pig blood in the experimental groups were somewhat higher than those in the control group were, but did not go beyond the physiological norm limits. By the end of the experiment, erythrocyte count in pig blood in the 1 st and 2nd experimental groups increased by 3.19 and $4.62 \%$, hemoglobin number increased by 2.12 and $2.83 \%(\mathrm{P}<0.05)$ with respect to the control group; it is an evidence of a better availability of oxygen in the organism and an intensive metabolism.

Protein and mineral availability of an organism are illustrated by total protein, calcium and phosphorus content in blood. Total protein, calcium and phosphorus content in the blood of pigs in the experimental groups were comparatively higher than those in the control group were, but did not go out of the physiological fluctuation limits; it is an evidence of intensive protein and mineral metabolism in the organisms. A higher concentration of total protein was found in the blood of pigs that got 2 and 3\% of dry diet weight in zeolite, which is 2.97 and $2.40 \%$ higher than in the control group; for calcium the numbers are $8.90(\mathrm{P}<0.05)$ and $11.02 \%(\mathrm{P}<0.05)$ higher, and for phosphorus 10.41 and $11.76 \%$ higher than in the control group. Total protein concentration in the blood of the pigs that got $4 \%$ of dry diet weight in zeolite exceeded control values by $1.46 \%$, concentration of calcium and phosphorus was 5.51 and $6.79 \%$ higher.

Immune system is a functional system that provides organism with individuality and integrity. The main function of the immune system is protection against infections, elimination of damaged and mutated cells of the organism itself. The main type of white blood cells is neutrophilic leukocyte or neutrophil. Depending on degree of maturity and nucleus form, there are segmentonuclear and band neutrophils. Increased ratio of these forms of leukocytes speaks of negative trends in the health 
status of animals [10]. During the raising, the number of various forms of leukocytes was within the limits of physiological norm in experimental pigs. Use of zeolite as $2 \%$ and $3 \%$ of dry weight of food facilitated reducing the ratio of band neutrophils by 1.20 and $1.16 \%(\mathrm{P}<0.05)$, that of segmentonuclear neutrophils by 0.30 and $1.00 \%$ in comparison to control.

Monocytes play an important role in organizing an immune response, as they have a high phagocytic activity, clear the blood stream, destroy both living and dead microorganisms, annihilate tissue debris and dead cells of the organism [11]. In the end of the experiment, higher monocyte count was registered in the organisms of female pigs pertaining to the 2 nd experimental group, significantly larger, by $1.63 \%(\mathrm{P}<0.05)$, than the control. In the 1st and 3rd experimental groups, monocyte concentration in blood increased by 1.04 and $0.97 \%$ compared to the control.

Lymphocytes provide efficient cell-mediated immunity, antibody response, ability of the organism to provide accelerated and heightened immune response. Introduction of zeolite into pig diet increased lymphocyte concentration in pig blood by $2.30-2.50 \%$ with respect to control, which is an evidence of mobilizing the body defenses.

It is known that zeolites are not only mineral carriers and sorbing agents of various food and metabolic toxins, but also stimulants that effectively influence animal growth and development. Efficiency of application of the natural minerals depends on many factors, including biological availability of mineral nutrients, as they are essential for vital organic processes and formation of chemical structure of all tissues. Efficiency of zeolite introduction into pig diet may be evaluated from dynamics of live weight that characterizes the degree of organism development during the ontogeny (Table 1).

TABLE I. DYNAMICS OF CHANGES IN LIVE WEIGHT OF GUINEA PIGS

\begin{tabular}{|c|c|c|c|c|}
\hline \multirow[t]{2}{*}{ Index } & \multicolumn{4}{|c|}{ Group } \\
\hline & Control & $\begin{array}{c}1 \\
\text { experiment } \\
\text { al }\end{array}$ & $\begin{array}{c}2 \\
\text { experiment } \\
\text { al }\end{array}$ & $\begin{array}{c}3 \\
\text { experiment } \\
\text { al }\end{array}$ \\
\hline $\begin{array}{l}\text { Live weight when } \\
\text { staged, } \mathrm{kg}\end{array}$ & $\begin{array}{l}18.7 \pm \\
0.42\end{array}$ & $\begin{array}{c}19.1 \pm \\
0.33\end{array}$ & $\begin{array}{c}18.7 \pm \\
0.47\end{array}$ & $\begin{array}{c}19.0 \pm \\
0.42\end{array}$ \\
\hline $\begin{array}{l}\text { Live weight at the } \\
\text { end of the } \\
\text { experiment, } \mathrm{kg}\end{array}$ & $\begin{array}{c}97.7 \pm \\
0.39\end{array}$ & $\begin{array}{l}111.4 \pm \\
0.92 * * *\end{array}$ & $\begin{array}{c}117.5 \pm \\
0.57 * * *\end{array}$ & $\begin{array}{l}112.3 \pm \\
0.93 * * *\end{array}$ \\
\hline $\begin{array}{l}\text { Average daily } \\
\text { gain as a whole } \\
\text { for experience, } \mathrm{g}\end{array}$ & $\begin{array}{c}438.9 \pm \\
5.55\end{array}$ & $\begin{array}{l}512.8 \pm \\
9.54 * * *\end{array}$ & $\begin{array}{l}548.9 \pm \\
11.1 * * *\end{array}$ & $\begin{array}{l}518.3 \pm \\
2.94 * * *\end{array}$ \\
\hline In $\%$ to control & 100 & 116.8 & 125.1 & 118.1 \\
\hline Gross increase, $\mathrm{kg}$ & $\begin{array}{c}79.0 \pm \\
0.99\end{array}$ & $\begin{array}{l}92.3 \pm \\
1.13^{* *}\end{array}$ & $\begin{array}{c}98.8 \pm \\
0.85^{* * *}\end{array}$ & $\begin{array}{c}93.3 \pm \\
0.85^{* * *}\end{array}$ \\
\hline
\end{tabular}

The female pigs in the 2 nd experimental group that got $3 \%$ of zeolite of dry weight of diet have shown the best results. While the initial weight of the animals was the same in the beginning of the experiment, gross gain per animal amounted to $98.8 \mathrm{~kg}$, live weight at the end of fattening was $117.5 \mathrm{~kg}$, which is $20.3 \%$ higher $(\mathrm{P}<0.001)$ than in the control group. Gross weight gain per animal in the 1st and the 3rd experimental groups had shown a reliable excess over the control values, by $16.8 \quad(\mathrm{P}<0.01)$ and $18.1 \% \quad(\mathrm{P}<0.001)$ respectively, live weight at the end of fattening was 14.0
$(\mathrm{P}<0.001)$ and $14.9 \% \quad(\mathrm{P}<0.001)$ higher, respectively. Maximum daily average gain in live weight was observed in female pigs pertaining to the 2nd experimental group, $25.1 \%$ $(\mathrm{P}<0.001)$ larger than the control. In the 1 st and the $3 \mathrm{rd}$ experimental groups the daily average increment in live weight exceeded the control values by $16.84(\mathrm{P}<0.001)$ and $18.10 \%$ $(\mathrm{P}<0.001)$ respectively.

Meat production is among the most important pig productivity criteria; it is largely determined by genetics, however, partially it depends on environmental factors, including feeding $[8,14]$. Intensive feeding throughout the growth period allows growing and fattening animals to a higher live weight with lower feed consumption. When feeding is insufficient, animal growth intensity reduces, fattening period extends and food costs increase. Carcasses of such animals are of a lower quality as they have more bones and connective tissue. Pork production provides the main part of growth in animal husbandry provides and has a good resource and investment potential [7]. Realizing maximum profits in pig farming is possible only by means of increased productivity of animals while rationally using local feed resources. When assessing meat productivity, preslaughter weight, chilled carcass weight and fat depth were taken into account (Table 2).

TABLE II. MEAT PRODUCTIVITY OF PIGS

\begin{tabular}{|l|c|c|c|c|}
\hline \multirow{2}{*}{ Index } & \multicolumn{4}{|c|}{ Group } \\
\cline { 2 - 5 } & Control & $\begin{array}{c}1 \\
\text { experiment } \\
\text { al }\end{array}$ & $\begin{array}{c}2 \\
\text { experimental }\end{array}$ & $\begin{array}{c}3 \\
\text { experiment } \\
\text { al }\end{array}$ \\
\hline $\begin{array}{l}\text { Prefabricated } \\
\text { live weight, } \\
\mathrm{kg}\end{array}$ & $\begin{array}{c}98.53 \pm \\
0.57\end{array}$ & $\begin{array}{c}113.20 \pm \\
0.64 * * *\end{array}$ & $\begin{array}{c}118.33 \pm \\
0.68^{* * *}\end{array}$ & $\begin{array}{c}110.47 \pm \\
0.72^{* * *}\end{array}$ \\
\hline $\begin{array}{l}\text { Weight of } \\
\text { refrigerated } \\
\text { carcass, kg }\end{array}$ & $\begin{array}{c}71.30 \pm \\
0.48\end{array}$ & $\begin{array}{c}84.06 \pm \\
0.73^{* * *}\end{array}$ & $\begin{array}{c}88.90 \pm \\
0.53^{* * *}\end{array}$ & $\begin{array}{c}81.62 \pm \\
0.43^{* * *}\end{array}$ \\
\hline $\begin{array}{l}\text { Slaughter } \\
\text { output, \% }\end{array}$ & $\begin{array}{c}72.36 \pm \\
0.10\end{array}$ & $\begin{array}{c}74.26 \pm \\
0.92^{*}\end{array}$ & $\begin{array}{c}75.13 \pm \\
0.12^{* * *}\end{array}$ & $\begin{array}{c}73.88 \pm \\
0.66\end{array}$ \\
\hline $\begin{array}{l}\text { Thickness of } \\
\text { bacon over 6- }\end{array}$ & $30.53 \pm$ & $28.13 \pm$ & $27.87 \pm$ & $28.80 \pm$ \\
7 thoracic & 0.71 & 0.74 & 0.64 \\
vertebra, mm & 0.88 & $0.74 .13 \pm$ & $31.87 \pm$ \\
\hline $\begin{array}{l}\text { The area of the } \\
\text { muscular eye, } \\
\text { cm }\end{array}$ & $29.80 \pm$ & $32.60 \pm$ & 34.74 \\
\hline $\begin{array}{l}\text { Weight of the } \\
\text { rear third of the } \\
\text { side, kg }\end{array}$ & $10.33 \pm$ & $12.43 \pm$ & $13.13 \pm$ & $12.00 \pm$ \\
\end{tabular}

Practicality of introducing zeolite into pig diet is supported by meat productivity values. Slaughter yield is an important indicator of meat-related qualities of animals; its value in experimental group exceeded the control values by 1.52 $2.77 \%(\mathrm{P}<0.001)$.

The highest chilled carcass weight and loin eye area was characteristic of the 2nd group, exceeding the control values by $24.68(\mathrm{P}<0,001)$ and $14.53 \%(\mathrm{P}<0.05)$ respectively. In the $1 \mathrm{st}$ and 3rd experimental groups the chilled carcass weight was $17.90(\mathrm{P}<0.001)$ and $14.47 \%(\mathrm{P}<0.001)$ larger and the loin eye area was 9.40 and $6.95 \%$ larger than in the control group.

Meat and fat qualities of pigs are also assessed by morphological composition and ratio of certain tissues as they define nutritional value, processing-related and culinary 
qualities of meat; such an assessment has shown that introduction of zeolite into pig diet allowed increasing the muscle tissue weight in half carcasses. The highest muscle tissue content was registered in the 2 nd experimental group, $1.80 \%$ higher than in the control group. In the 1 st and 3 rd experimental groups, muscle tissue content increased by 1.20 and $0.87 \%$ compared to the control. The half carcasses of pigs from the 2 nd experimental group have shown fat tissue content $2.56 \%$ lower than that of the control group pigs. In the $1 \mathrm{st}$ and 3 rd experimental groups, fat content was 1.75 and $1.06 \%$ lower compared to the control.

Mineral content of the meat largely depends on adequacy of the animal's diet. Introduction of zeolite sources from Lyulinskoye deposit has not only increased meat nutritional value, but mineral concentration values as well. The muscle tissue of pigs from the 2nd and 3rd experimental groups had advantageous difference from the control group: calcium content was 16.67 and 5.56\% higher, phosphorus content 9.26 and $5.56 \%$ higher, magnesium content 5.13 and $10.26 \%$ higher, zinc content 5.06 and $1.83 \%$ higher, manganese content 25.00 and $35.00 \%$ higher. In the 1 st experimental group, the amount of phosphorus in the muscular tissue was $7.41 \%$ higher than in the control group, the amount of manganese was $10.00 \%$ higher, the amount of zinc was $5.67 \%$ higher, but magnesium and calcium content was lower by 21.87 and $5.88 \%$ respectively.

Degree of internal organs development is one of the indicators of physiological condition and the level of increased productivity in pigs. The best results in the internal organs development has been shown by the female pigs in the 2 nd experimental group; their heart weight exceeded that of the control group by $4.31 \%(\mathrm{P}<0.01)$; the excess of weight was $7.29 \%(\mathrm{P}<0.001)$ for lungs, $10.77 \% \quad(\mathrm{P}<0.01)$ for spleen, $12.38 \%(\mathrm{P}<0.001)$ for liver, 7.84\% $(\mathrm{P}<0.01)$ for kidneys. The heart weight in pigs of the 1 st and 3 rd experimental groups was $2.51(\mathrm{P}<0.05)$ and $1.22 \%$ higher, weight of lungs was 3.96 $(\mathrm{P}<0.01)$ and $2.84 \%(\mathrm{P}<0.01)$ higher, weight of spleen was 6.61 $(\mathrm{P}<0.05)$ and 3.64\% higher, weight of liver was $7.58(\mathrm{P}<0.001)$ and $3.76 \% \quad(\mathrm{P}<0.01)$ higher, weight of kidneys was 2.92 $(\mathrm{P}<0.05)$ and $2.43 \%(\mathrm{P}<0.05)$ higher compared to the control values. It is likely, that thanks to its adsorption, detoxification and ion exchange qualities, zeolite sourced from Lyulinskoye deposit reduced the toxicity of harmful substances coming with the animal feed, activated metabolic processes and improved gas metabolism, which had a positive impact in growth and development of internal organs.

During the life, the internal organs perform various functions determining animal growth and development, quantitative content of main tissues in animal body [6]. They take a significant place in nutritional balance, as they are an additional food resource. They significantly vary in nutritional and biological value, structure, storage stability and taste. Introduction of zeolite led to increase in mineral content in the internal organs. The highest amount of minerals in heart and liver was registered in the female pigs of the 2 nd experimental group, magnesium content was 6.67 and $8.57 \%$ higher, manganese content was 38.89 and $31.98 \%(\mathrm{P}<0,01)$ higher, 2007copper content was 10.73 and $23.98 \%(\mathrm{P}<0,001)$ higher, zinc content was $28.16(\mathrm{P}<0.01)$ and $4.71 \%(\mathrm{P}<0,01)$ higher than the corresponding values in the control group. In the 1 st and 3rd experimental groups, manganese content in heart exceeded the control values by 24.07 and $53.70 \%$, copper content was higher by 14.12 and $20,34 \%$, zing content was higher by $24.14(\mathrm{P}<0.05)$ and $25.86 \%(\mathrm{P}<0.01)$; for minerals in liver the values are, respectively $22.67(\mathrm{P}<0.001)$ and $33.72 \%$ $(\mathrm{P}<0.05) ; 17.86(\mathrm{P}<0.001)$ and $28.57 \%(\mathrm{P}<0.001) ; 2.98$ and $5.95 \%$ higher than the control values.

Introduction of zeolite as 2 and $3 \%$ of dry feed weight led to the gross gain in the live weight of pigs being increased by 16.83 and $25.96 \%$, profit grew by 391.36 and 571.1 rubles, level of profitability grew by 4.34 and $5.94 \%$, while the costs per 1 $\mathrm{kg}$ of live weight reduced by 3.80 and $5.19 \%$ as compared to the control. Introduction of zeolite as $4 \%$ of dry feed weight also had positive impact on gross increment in live weight, increasing it by $18.10 \%$, at that, however, cost of $1 \mathrm{~kg}$ of live weight increment increased by $5.96 \%$, leading to a reduction in profits by 264.39 rubles as compared to the control.

Thus, use of zeolite sourced from Lyulinskoye deposit in Khanty-Mansi Autonomous Region allowed improving metabolism, activating body defenses, increasing nutrient digestibility, productive and meat-related qualities of pigs, while simultaneously reducing feed costs and leading to realization of additional profit

\section{References}

[1] A.A. Bakharev Study of acclimatization and adaptation of livestock breeds Limousine and salers, the development of methods for their effective use. Abstract of the doctoral dissertation, Kurgan, p. 40, 2013.

[2] G.I. Boryaev, Yu.N. Fedorov, A.A. Kuznetsov, N.S. Starostina, Pork quality indicators when introducing a biologically active selenopyran compound into the diet, Agricultural Biology, № 4, pp. 96-100, 2008.

[3] S.R. Bulankova, The use of highly disperse mineral sorbents for the prevention of animal poisoning by toxic elements and T-2 toxin. The Author's abstract of the dissertation of the candidate of biological sciences. Kazan, p. 20, 2012

[4] L. Buldakov, On the favorable effect of small doses of ionizing radiation on the development of organisms and human health, The Bulletin on Atomic Energy, № 2, pp.62-67, 2004.

[5] P.V. Karbolin, A.A. Ovchinnikov, Productivity of broiler chickens when using various sorbents in rations, Bulletin of TGSKhA, № 4, pp.84-85, 2009

[6] I.N. Mikolajchik, A.P. Bulatov, Feeding young pigs: theory and practice Kurtamysh State Unitary Enterprise "Kurtaiysh Printing House", 2008.

[7] A.T. Mysik The development of livestock in the world 2000 - 2009 years, Zootechny, №1, pp.2-6, 2012.

[8] O.M. Popov, T.M. Giro, Optimization of fodder rations for livestock to improve the quality of meat raw materials, Meat Industry, №1, pp. 38-40, 2012.

[9] A.B. Satkeeva, A.M. Okunev, Physico-chemical and radioactive properties of the zeolite and its effect on productivity, and some physiological parameters of the pigs, Feeding of farm animals and fodder production, № 8, pp.34 - 38, 2012

[10] V.G. Skopichev et al, Physiology of animals and ethology. Moscow: Kolos, p. 720, 2003

[11] V.G. Skopichev, V.I Yakovlev, Private physiology, Moscow: Kolos, p. 555, 2008.

[12] V.D. Starikov, V.I. Migunov, Radiation ecology. Tyumen: OJSC Tyumen Printing House, p. 400 p.

[13] N.I. Strekozov, I.I. Moshkutelo, N.V. Sivkin, V.I. Chinarov, A.V Chinarov, A.I. Tikhomirov Substantiation of promising technologies in cattle breeding, Journal of VNIIMZH, №2 (22), pp. 36-43, 2016. 
[14] A. Struk, M. Spivak, E. Abdroziakova, T. Egorova, N. Solovyanova, etc. Use of new biologically active additives in the production of beef, Milk and Meat Cattle, 2010, №1, pp.26-28.

[15] G.A. Yarmots, A.B. Satkeeva, L.P. Yarmots, Use of natural feed additives to increase the productivity of animals, Feeding of farm animals and fodder production, №4, pp. 16-25, 2016. 